\title{
Salve Dosage Form
}

National Cancer Institute

\section{Source}

National Cancer Institute. Salve Dosage Form. NCI Thesaurus. Code C42980.

A semi-solid composed of a thick, fat or wax-based ointment or cerate with a

consistency somewhere between an ointment and a plaster. 